\title{
TCMB Ağırlıkıı Ortalama Fonlama Maliyeti’nin BİST100 Üzerindeki Etkisi
}

\section{The Effect of Weighted Average Cost of The CBRT Funding on BÍST100}

\author{
Ramazan EKİNCİ, Dokuz Eylül Üniversitesi, Türkiye, ramazan.ekinci@ deu.edu.tr \\ Fatih CEYLAN, Dokuz Eylül Üniversitesi, Türkiye, fatih.ceylan@deu.edu.tr \\ Osman TÜZÜN, Dokuz Eylül Üniversitesi, Türkiye, osman.tuzun@ deu.edu.tr \\ Hakan KAHYAOĞLU, Dokuz Eylül Üniversitesi, Türkiye, hakan.kahyaoglu@ deu.edu.tr
}

\begin{abstract}
Öz: Merkez Bankalarının para politikası araçlarının etkinliği ve bu araçların piyasa üzerindeki etkisi; para politikası araçlarının hedeflenen değişskenleri ile para ve finansal piyasaların göstergelerinin oynakllkları üzerindeki etkisine bağl olarak analiz edilmektedir. Genel kabule göre merkez bankalarının uyguladıkları veya açılkladıkları önlemler finansal göstergelerde oynaklık düşüşüne neden olmalıdır. Bu çalışmada Türkiye Cumhuriyet Merkez Bankası'nın (TCMB) uygulamış olduğu faiz politikasinın Borsa İstanbul-100 (BİST100) endeksi üzerindeki etkisi Moon ve $Y$ Y (2010)'un yaklaşımına dayall olarak simetrik ve asimetrik GARCH modelleriyle test edilmektedir. Elde edilen sonuçlara göre ağırlkkl ortalama fonlama maliyetinden kaynaklanan bir şok simetriktir ve bu simetrik şok oynaklık yayılımına yol açmamaktadır. Sonuç olarak, Türkiye'de ăğrllkl ortalama fonlama maliyetinin BíST100 üzerinde bir etkisinin olmadı̆ğ ifade edilebilir.
\end{abstract}

\section{Anahtar Kelimeler: AOFM, BíST100, MV-GARCH, Oynaklik Yayllımı.}

Abstract: The effectiveness of monetary policy instruments of the Central Banks and the impact of these tools on the market are analyzed depending on the effects of monetary policy tools on the targeted variables, and the volatility of the indicators of monetary and financial markets. According to common view, the measures which are applied or announced by central banks lead to a volatility decrease in the financial indicators. In this study, the effects of the interest rate policy of the Central Bank of the Republic of Turkey (CBRT) on BIST100 index are tested by symmetric and asymmetric GARCH models based on Moon and $Y u$ (2010)'s approach. In accordance with the obtained results, a shock which is derived from the weighted average cost of the CBRT funding is symmetric and this symmetric shock does not have any influence on BIST100. As a result, it can be said that the weighted average cost of the CBRT funding does not have any influence on BIST100.

Keywords: WACF, BISST100, MV-GARCH, Volatility Spillover.

\section{Giriş}

Merkez Bankalarının en önemli görevlerinden biri finansal piyasaların ve kurumların istikrarlı olarak işlevlerini yerine getirmesi amacına yönelik olarak likidite yönetimidir (Knütter, Mohr ve Wagner: 2011). Kısa dönemde finansal piyasalarda alım ve satıma konu olan finansal araçların fiyatları veya bunların ortak göstergeleri olan endekslerin değerlerinde bir oynaklık artışı var ise bir istikrarsızlık göstergesi olarak tanımlanmaktadır. Finansal piyasalardaki oynaklık artışları genel olarak merkez bankalarının likidite açısından müdahalesine yol açmaktadır. Bu müdahaleler kısa dönemde oynaklık azalışına yapmış olduğu etkiye göre değerlendirilmektedir. Bundan dolayı merkez bankalarının finansal piyasalara müdahalesinin sonucunda gerçekleşen likidite maliyetleri de; ekonomideki karar birimlerinin likidite ile finansal araçların arasındaki tercihlerini etkilemiş olacağı ifade edilebilir.

Son yıllarda finansal serbestleşme ve teknolojik ilerlemeler ile birlikte hisse senedi piyasaları ile para piyasaları arasında etkileşim artmaktadır. Hisse senedi endekslerinde ve faiz oranlarında meydana gelen değişmeler, ülkelerin ekonomik temellerinde değişiklikler meydana getirmektedir. Hisse senedi piyasası ve faiz oranları arasındaki ilişki yatırımcılar, portföy yöneticileri, politika belirleyicileri için önemli olduğu gibi portföy dağılımı ve yönetimi, risk yönetimi ve parasal aktarım mekanizması gibi finansal piyasalar için de önemlidir ( Ferrer ve diğerleri, 2016: 1). $\mathrm{Bu}$ piyasalar arasında meydana gelen güçlü etkileşim sadece yatırımlar ve risk yönetimi için değil aynı zamanda ekonomik ve finansal istikrar için de önemlidir. Oynaklık bulaşıcılığının olmadı̆̆ı durumlarda politika yapıcılar bulaşıcılığı engellemek için aktif bir politika yürütmezler. Ancak politika yapıcıların, bulaşıcılığın olduğu durumlarda riskten kaçınmak ve finansal istikrarın sağlanması adına, oynaklık geçişlerinin bu piyasalar arasında nasıl gerçekleştiğini anlamak ve bulaşıcılığı engellemek için uygun politikalar geliştirmeleri gerekmektedir (Şensoy ve Sobac1, 2014: 449).

TCMB politika faiz oranı olan bir haftalık repo, faiz koridorunun üst sınırı olan borç verme faiz oranı ile ekonominin likidite talebini karşılamaktadır. Ancak söz konusu likiditenin fiyatı bir haftalık repo faiz oranı gibi görünse de, bu likiditenin fiyatı belirtilen diğer likidite araçlarının maliyetine göre de değişmektedir. Bu durumda söz konusu likiditeyi sağlamaya yönelik oluşan fiyatların ağırlıklı ortalaması, piyasa için likiditenin maliyetini oluşturmaktadır. Bundan dolayı bu ağırlıklı ortalama "ağırlıklı ortalama fonlama maliyeti (AOFM)" olarak ifade edilmektedir. Buna göre TCMB'nin diğer araçlarla likiditenin maliyetini etkiliyor olmasının özellikle hisse senetleri piyasasına olası bir etkisinin olup olmadığı önem kazanmaktadır. Buradan hareketle bu çalışmada TCMB'nin piyasaya vermiş olduğu likidite çerçevesinde oluşan faiz oranının (ağırlıklı ortalama fonlama maliyeti) Borsa 
İstanbul Hisse Senedi Piyasası oynaklığı üzerinde etkisiyle birlikte hisse senetleri piyasasının değişkenliği üzerinde merkez bankasının likidite yönetiminin etkisinin analizi amaçlanmaktadır. Böylece çalışmanın bulguları kısa dönemde hisse senedi ve Tobin Q parasal aktarım mekanizması kanallarının varlığına da işaret etmektedir (Mishkin, 2001: 1). Ayrıca analiz sonuçlarıyla pozitif veya negatif bir likidite şokunun hisse senetleri piyasasının oynaklığı üzerindeki etkisi de incelenmiş olmaktadır.

Bu çalışmada ele alınan verinin yüksek frekanslı olması ve TCMB'nin piyasa üzerindeki etkisinin oynaklıklar bağlamında analiz edilmesinden dolayı; TCMB'nin uygulamış olduğu faiz politikasının Borsa İstanbul-100 (BİST100) endeksi üzerindeki etkisi Moon ve Yu (2010) yaklaşımına dayalı olarak simetrik ve asimetrik GARCH modelleriyle test edilmiştir. Elde edilen bulgular doğrultusunda Merkez Bankası'nın ağırlıklı ortalama fonlama maliyetlerinden BIST100 endeksine doğru simetrik ve asimetrik bir oynaklık yayılımının olup olmadığı ortaya konmuştur. TCMB'nin ortalama fonlama maliyetinin değişkenliğinden Borsa İstanbul oynaklığına bu çalışmada kullanılan yaklaşıma göre bir nedensellik bulunmamıştır.

Beş bölümden oluşan çalışmanın ikinci bölümünde literatür taraması, üçüncü bölümde araştırma çerçevesinde uygulanan yöntem tanıtılmış olup, dördüncü bölümde veri seti ve ampirik analiz sonuçlarına yer verilmiştir. Beşinci olarak sonuç bölümünde ulaşılan bulgular çerçevesinde politika önerileri ortaya konulmuştur.

\section{Literatür Taraması}

Finans literatüründe farklı hisse senedi piyasaları arasında oynaklık yayılımının etkileriyle ilgili bilgi sağlayan sayısız çalışma bulunmaktadır. Bilginin bir piyasadan diğer piyasaya nasıl yayıldığıyla ilgili bilgi farklı piyasalarda yatırım kararı alan birçok yerli ve yabancı yatırımcı için temel odak noktasıdır. Genellikle literatürde oynaklık yayılımının modellenmesi ile ilgili farklı yaklaşımlar dikkat çekmektedir. Bu yaklaşımların başında koentegrasyon analizleri, çok değişkenli otoregresif koşullu değişen varyans (MGARCH) modelleri, varyans nedensellik testleri, rejim-değişim ve stokastik oynaklık modelleri gelmektedir.

Granger nedensellik testi genellikle zaman serileri arasındaki doğrusal ilişkinin testinde kullanılmaktadır. Ancak finansal değişkenlerdeki oynaklık zamana göre değiştiği için finansal zaman serilerinde nedensellik testleri genellikle serinin ikinci momentine(varyans) dayanmaktadır. Varyans nedensellik testi ilk olarak Cheung ve $\mathrm{Ng}$ (1996) daha sonra ise Hong (2001) ve Herwartz (2006) tarafından geliştirilmiş ve genellikle oynaklık yayılımının yönünü belirlemek amacıyla kullanılmıştır. Cheung ve $\mathrm{Ng}$ (1996) nedensellik testinde tek değişkenli GARCH modelinin hata karelerinin karşılıklı korelasyon fonksiyonunu kullanırken, Herwartz (2006) tarafından geliştirilen varyans nedensellik testi LM test istatistiğine dayanmaktadır.

Hu vd. (1997) çalışmalarında Shenzhen, Shanghai, Hong Kong, ve Taiwan olmak üzere dört gelişmekte olan ülke borsası ile USA ve Japanya'da gelişmiş hisse senedi piyasaları arasında günlük veriler kullanarak oynaklık yayılımını test etmişlerdir. Granger nedensellik testine dayanarak yapılan varyans nedensellik testi sonucunda Hong Kong ve USA piyasaları arasında bir oynaklık yayılımının olduğu bulgusuna ulaşmışlardır.

Elyasiani ve Mansur (1998), GARCH-M tekniği yardımıyla faiz oranı ve oynaklığının banka hisse getirileri üzerindeki etkisini incelemiştir. Yazar faiz oranı ve oynaklığındaki değişimin bankanın hisse getirilerinin birinci ve ikinci momentleri üzerinde doğrudan bir etkisinin olduğu sonucuna ulaşmıştır.

Kanas ve Kouretas (2002) çalışmasında 1976-1993 dönemine ait aylık veriler kullanarak dört Latin Amerika piyasasında döviz kurları arasındaki oynaklık yayılımını ortalama ve varyans nedensellik testleri yardımıyla incelemektedir. Çalışmada Cheung ve $\mathrm{Ng}$ (1996) tarafından geliştirilen varyans nedensellik testi kullanılmıştır. Elde edilen sonuçlara göre ülkelerin döviz kurlarının arasında asimetrik bir oynaklık yayılımı olduğu sonucuna EGARCH-M tekniği kullanarak ulaşmışlardır. Bu sonuca göre ele alınan piyasalar arasında hem ortalamada hem de varyansta bir oynaklık yayılımıyla nedenselliğin olduğu sonucuna ulaşılmıştır.

Alaganar ve Bhar (2003) çalışmalarında 7 OECD ülkesi için finansal sektör getirileri ve faiz oranı arasındaki ilişkiyi Cheung ve Ng (1996) tarafindan geliştirilen varyans nedensellik testini kullanarak incelemiştir. Bu çalışmanın sonucuna göre faiz oranlarıyla finansal sektör getirileri arasında gecikmeli ve iki yönlü ortalama ve varyans nedenselliği olduğu görülmüştür.

Czaja vd. (2009) ve Korkeamäki (2011) çalışmalarında faiz oranlarındaki dalgalanmaların hisse senedi getirileri üzerindeki etkisinin zamanla azaldığı ve azalmadaki en önemli faktörün faiz oranı risklerine karşı geliştirilen korunma araçlarının olduğu sonucuna varmışlardr. Yazarlar ayrıca hisse senedi getirilerinin kısa dönem faiz oranlarına kıyasla uzun dönem faiz oranlarından daha fazla etkilendiği bulgusuna ulaşmışlardır.

Okur ve Çevik (2013) gün içi verileri kullanarak spot fiyatlar ve gelecek fiyatlar arasındaki oynaklık yayılımını Hong (2001) ve Hafner ve Herwartz (2006) tarafından geliştirilen varyans nedensellik testleriyle incelemişlerdir. Elde edilen sonuçlara göre spot fiyatları gelecek fiyatların Granger nedeni bulunmuş diğer bir ifadeyle spot fiyatların Türkiye'de fiyatların oluşumunda büyük bir öneme sahip olduğu bulgusuna ulaşılmıştır.

Martínez vd (2015), çalışmalarında 1993M1 ve 2012M10 dönemine ait aylık verileri kullanarak İspanya'da faiz oranları ve hisse senedi piyasası arasındaki ilişkiyi wavelet (dalgacıklar) yaklaşımını kullanarak incelemişlerdir. Elde edilen wavelet analizi sonuçlarına göre İspanya hisse senedi piyasalarının faiz oranlarına karşı duyarlı olduğunu ve bu duyarlılığın düzeyinin zaman boyutuna ve endüstrilere göre değiştiği bulgusuna ulaşmışlardır. 
González (2016) çalışmasında 1 Ocak 1996 ve 31 Kasım 2014 dönemine ait günlük veriler kullanarak farklı bölgelerdeki(ABD, Asya ve Avrupa) hisse senedi piyasalarını kendi içinde gruplandırarak bunlar arasındaki asimetrik ilişkiyi ortalama ve varyans nedensellik analizleriyle test etmektedir. Çalışmada öncelikle ortalamavaryans (AR-GARCH) modeli tahmin edilmektedir. Daha sonra ise tahmin edilen modelden elde edilen standartlaştırılmış hatalar ortalama ve varyans nedensellik testlerinde kullanılmaktadır. Elde edilen ortalama ve varyans nedensellik sonuçlarına göre açılış ve kapanış saatlerinin farklı olması nedeniyle gruplandırılan piyasalar arasında asimetrik bir oynaklık yayılımının varlığı görülmektedir.

Sweeney ve Warga (1986) faiz oranı ve hisse senedi piyasası arasındaki ilişkiyi iki faktörlü Arbitraj Fiyatlama Teorisi (APT) çerçevesinde ele alarak değerlendirmişlerdir. Çalışmada 1960-1979 dönemi için hisse senetlerinin ve devlet tahvillerinin getirileri dikkate alınmıştır. Çalışmanın bulgularına göre; faiz oranları ile söz konusu finansal araçlar arasında anlamlı bir ilişki söz konusudur.

Korkeamäki (2011), 1990-2006 dönemi için çoğunluğu Avrupa Birliği ve Parasal Birlik üyesi olan ülkelerde hisse senedi piyasalarının faiz oranı ile olan ilişkilerini değerlendirmiştir. Çalışmanın bulgularına göre Euro öncesinde faiz oranı ile hisse senedi getirileri arasında negatif yönlü bir ilişki bulunmuştur. Ayrıca çalışmada ilgili dönemde Avrupa Birliği’nde firmaların faiz oranı riskini başarılı bir şekilde yönettikleri sonucuna ulaşılmıştır.

Campbell ve Ammer (1991), 1952-1987 dönemi aylık verileri ile log-doğrusal varlık fiyatlama ve VAR yaklaşımlarını kullandıkları çalışmalarında; hisse senetlerinin sermaye kazançlarının, enflasyonun, faiz oranlarının gelecekte beklenen değerlerin hisse senedi piyasasında meydana getirdiği etkiler araştırılmıştır. Çalışmaya göre; uzun vadeli finansal varlıkların enflasyonun gelecekteki beklenen değerinden etkilendiği ancak reel faiz oranlarının (kısa vadeli nominal faiz oranlarını ve bunların vade yapıları üzerinde etkili olmalarına rağmen) uzun vadeli finansal varlıklar üzerinde etkileri sınırlıdır.

Bjørnland ve Leitemo (2009), ABD para politikası ile S\&P500 arasındaki karşılıklı bağımlılığı incelemişlerdir. 1983M1-2002M12 zaman aralığında kısa ve uzun dönemli kısıtların bulunduğu Yapısal VAR yaklaşımı ile elde edilen bulgulara göre S\&P500 ile ABD para politikası değişkenleri arasında güçlü bir karşılıklı bağımlılık bulunmuştur.

Laopodis (2013) çalışmasında hisse senedi piyasası ile para politikası arasındaki dinamik bağlantıyı, ilgili dönemlerin Fed başkanları olan Burns, Volcker ve Greenspan dönemlerini para politikası rejimleri olarak ayırarak incelemiştir. Çalışmada 1970:01-1979:08 (Burn), 1979:08-1987:08 (Volcker) ve 1987:08-2005:12 (Greenspan) olmak üzere üç dönem VAR analiziyle incelenmiştir. Çalışmanın bulgularına göre hisse senedi piyasası ile para politikası arasında kalıcı ve istikrarlı bir bağlantı bulunamamıştır.

Das (2005), Hindistan, Pakistan ve Bangladeş için 1985-2003 dönemini kapsayan çalışmasında hisse senedi piyasası ile faiz oranları arasındaki ortak bir trendin varlığını araştırmıştır. Söz konusu süreç eş bütünleşme yöntemi ile analiz edilmiştir. Çalışmanın bulgularına göre Hindistan hariç diğer ülkelerde hisse senedi piyasası ile faiz oranları arasında güçlü bir ilişki bulunmuştur.

Panda (2008) Hindistan'da faiz oranlarının hisse senedi piyasası üzerinde ne derece etkili olduğunu incelemiştir. 1996-2006 dönemi aylık verilerinin kullanıldığı çalışmada Vektör Hata Düzeltme Modeli (VECM) uygulanmıştır. Uygulama sonuçlarına göre; kısa dönem faiz oranları hisse senedi piyasasını pozitif yönde etkilerken, uzun dönem faiz oranları negatif yönde etkilemektedir.

Shah vd. (2012) faiz oranları ile hisse senedi piyasası arasındaki ilişkiyi Eş bütünleşme ve VAR temelli Granger nedensellik testleri ile analiz etmişlerdir. Çalışmada Pakistan için 2007-2010 döneminde söz konusu değişkenler için uzun dönemli bir ilişki bulunamamıştır Ayrıca nedensellik testi sonuçlarına göre; faiz oranları hisse senetlerinin Granger nedeni iken, hisse senetlerinin faiz oranlarının Granger nedeni olmadığı sonucuna da ulaşılmıştır.

Ferrer vd. (2016) önde gelen Avrupa ülkeleri için, uzun vadeli faiz oranları ve hisse senedi getirileri arasındaki bağlantıyı zaman ve frekans boyutlu analiz yapmaya olanak tanıyan Wavelet yaklaşımıyla araştırmışlardır. Uygulama sonuçlarına göre, söz konusu değişkenler arasında en yüksek karşılıklı bağımlılığı İngiltere göstermektedir. Hisse senedi piyasası ile faiz oranları arasındaki bağlantının en yüksek seviyelere çıkması 2007 2008 krizinin başlangıcından itibaren söz konusu olmuştur.

Flannery ve James (1984), nominal faiz oranlarındaki değişmelerin hisse fiyatları üzerindeki etkisini bir firmanın elinde tuttuğu varlıkların vade yapısı ile ilişkili olduklarını tespit etmişlerdir. Özellikle ticari bankalar için faiz oranlarındaki değişmeler ile hisse senedi fiyatlarındaki değişmeler arasında anlamlı bir ilişki bulmuşlardır.

Dinenis ve Staikouras (1998), çalışmalarında İngiltere'de faiz oranlarının finansal kurumların portföylerindeki hisse senedi getirileri üzerindeki etkilerini incelemişlerdir. Hem finansal kuruluşları hem de finansal olmayan şirketleri aldıkları çalışmalarında ilk olarak hisse senedi getirileri ile faiz oranları arasında anlamlı ve negatif bir ilişki bulmuşlardır. İkinci olarak faiz oranının varyansı olarak kullanılan faiz oranlarının oynaklığı hem finansal hem de finansal olmayan şirket getirilerini pozitif etkilemektedir.

Rigobon ve Sack (2004), yüksek frekanslı verilerde değişen varyans olma durumuna dayalı yeni tahminleme yöntemi geliştirdikleri çalışmalarında kısa vadeli faiz oranlarındaki artışın hisse senedi fiyatlarının azalmasına neden olduğunu bulmuşlardır. Buna bağlı olarak getiri eğrisinde yukarı doğru kaymanın uzun vadede küçüleceği sonucuna ulaşmışlardır. 
Ehrmann ve diğerleri (2005), 1989-2004 yılları arasındaki dönemi kapsayan çalışmalarında Euro bölgesi ve ABD arasında finansal piyasalardaki şokların bulaşıcılığını incelemişlerdir. Çalışmalarında ABD'de tahvil getirilerinin yanı sıra hisse senedi piyasalarının kısa vadeli faiz oranlarından daha fazla etkilendiği sonucunu bulmuşlardır. Buna karşılık Euro bölgesinde kısa vadeli faizler ve hisse senedi piyasaları ABD piyasalarına kıyasla tahvil getirileri ve döviz kurundan oransal olarak daha fazla etkilenmektedirler.

Bohl ve diğerleri (2008), çalışmalarında Avrupa Merkez Bankası'nın beklenmedik faiz kararlarının Avrupa hisse senedi piyasası getirileri üzerindeki etkisini tahmin etmişlerdir. Avrupa Merkez Bankası tarafından uygulanan bir para politikası şoku (kısa vadeli faiz oranlarının artırılması) Avrupa hisse senedi piyasaları getirisi üzerinde anlamlı ve negatif tepki verdiğini tespit etmişlerdir.

Kholodilin ve diğerleri (2009), çalışmalarında Avrupa Merkez Bankasının uyguladığı para politikasının toplam ve sektörel olarak Avrupa hisse senedi piyasası üzerinde etkisini araştırmışlardır. Faiz oranlarında ani bir artış sektörel bazlı hisse senedi piyasasında getirilerin azalmasına yol açmaktadır. Hisse senedi piyasası bir bütün olarak ele alındığında da faiz oranlarında ani bir artış hisse senedi piyasalarında getirileri azalttığını tespit etmişlerdir.

Kasman, Vardar ve Tunç (2011) çalışmalarında EKK ve GARCH tahmin yöntemlerini, 27 Temmuz 1999-9 Nisan 2009 yılları arasında günlük veriler kullanarak faiz oranı ve döviz kurunun Türkiye'deki bankaların hisse getirileri üzerine etkilerini araştırmışlardır. Buna göre faiz oranı ve döviz kurunda meydana gelen değişmeler koşullu banka hisse getirilerini anlamlı ve negatif etkilemektedir. Ayrıca sonuçlar faiz oranı ve döviz kuru oynaklıklarının, koşullu banka hisse senedi getirilerinin oynaklıklarını etkileyen temel belirleyiciler olduğu sonucunu bulmuşlardır.

Faff vd. (2005) faiz oranı ve faiz oranı oynaklıkları değişiminin Avustralya finansal sektörü hisse getirilerinin dağılımın ortalama ve varyansı üzerinde ikili etkisini analiz etmişlerdir. 1978-1998 yılları arasında aylık veriler kullanmışlardır. Çok değişkenli GARCH-M yöntemi kullanılan çalışmada Avustralya'da deragülasyonun faiz oranları ve büyük banka hisse senetleri getirileri arasında temel ilişkiyi değiştirdiği tespitinde bulunmuşladır. Deragülasyon öncesi negatif olan ilişki deragülasyon sonrası pozitif olarak bulunmuştur.

$\mathrm{Bu}$ çalışmada ele alınan dönem, kullanılan yöntemler ve genellikle çalışmalarda kullanılan politika faizi yerine piyasa için likiditenin maliyetini oluşturan ağırlıklı ortalama fonlama maliyeti değişkeninin kullanılması bakımından diğer benzer çalışmalardan farklılık göstermektedir.

\section{Yöntem: Moon ve Yu Varyans Nedensellik Testi}

Bu çalışmada simetrik ve asimetrik GARCH modellerinin yanı sıra karşılıklı nedenselliğin analizi için Moon ve Yu (2010)'un yaklaşımına dayalı olarak geliştirilen yaklaşımlar kullanılmıştır. Söz konusu yöntemin en belirgin özelliği iki piyasa arasındaki oynaklık yayılımına (spillover) ve geçişgenliğine (pass-through) olanak vermesidir (Moon ve Yu: 2010).

İki aşamadan oluşan yaklaşımın birinci aşamasında oynaklığın şok olarak çıktığı piyasaya (LNDAOFM) ait diğer bir değişle dişsal değişkene ait AR(1)-GARCH(1,1)-M modeli tahmin edilmekte ve buradan modelin hata terimi elde edilmektedir. İkinci aşamada ise oynaklığın yayıldığı piyasa (LNDBİST100) bağımlı değişken olarak ele alınırken, tahmin edilen oynaklık denkleminin ortalama bölümüne bağımlı (LNDBİST100) ve bağımsız değişkenin (LNDAOFM) bir gecikmesi, varyans kısmına ise bağımsız değişkenin(şokun çıktığı piyasa) hatalarının karesi dâhil edilmektedir. Tahmin edilen denklemin varyans kısmındaki hatalarının karesine ait katsayının anlamlı olup olmamasına bağlı olarak oynaklık yayılımının olup olmadığına karar verilmektedir. Eğer hata karelerine ait katsayı anlamlı ise oynaklığın şok olarak çıktığı piyasadan diğer piyasaya doğru bir oynaklık yayılımının olduğu yönünde bir bulguya ulaşılmış olmaktadır.

\section{Veri Seti ve Ampirik Bulgular}

Çalışmada 2/21/2013 - 7/26/2016 dönemine ait Borsa İstanbul 100 Endeksi ve Merkez Bankası Ağırlıklı Ortalama Fonlama Maliyetine ait günlük veriler (1252 gözlem) kullanılmıştır. Söz konusu veriler TCMB-EVDS'den ve Borsa İstanbul veri tabanından elde edilmiştir. Değişkenleri temsil eden günlük zaman serileri düzey serilerden aşağıdaki formül yoluyla hesaplanmıştır.

$$
R_{t}=\ln \left(P_{t} / P_{t-1}\right)
$$

Analizlerde kullanılan değişkenler ve tanımları Tablo 1'de verilmektedir.

Tablo 1: Kullanılan Değişkenler ve Tanımları

\begin{tabular}{|l|l|}
\hline \multicolumn{1}{|c|}{ İndex } & Tanımı \\
\hline BİST100 & Borsa İstanbul 100 Endeksi \\
\hline AOFM & Merkez Bankası A ğırlıklı Ortalama Fonlama Maliyeti \\
\hline LNDBİST100 & Logaritmik Fark Borsa İstanbul 100 Endeksi \\
\hline LNDAOFM & Logaritmik Fark Merkez Bankası Ağırlıklı Ortalama Fonlama Maliyeti \\
\hline
\end{tabular}

Şekil 1'de finansal zaman serilerinin taşıdığ özelliklerin tespiti amacıyla değişkenlerin zamana göre eğilimlerini gösteren grafikler yer almaktadır. 

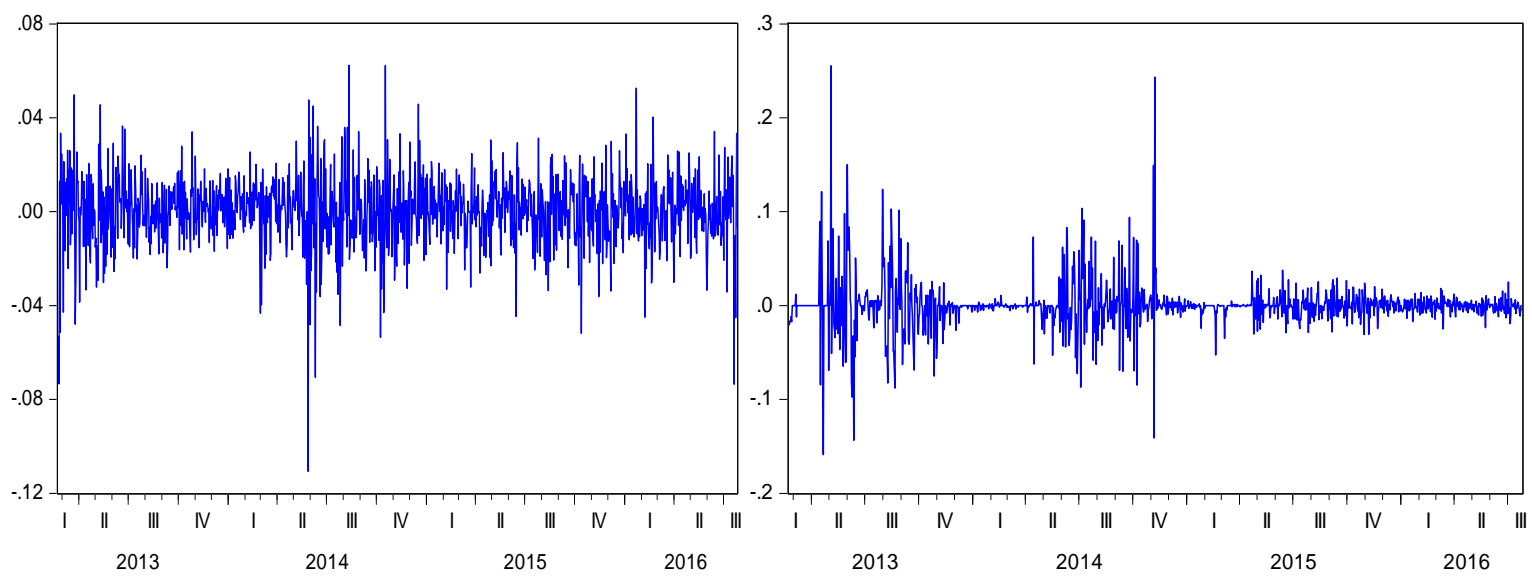

Sekiller incelendiğinde oynaklıkların genellikle birbirini takip ettiği, yüksek oynaklıkları yüksek oynaklıkların, düşük oynaklıkları ise yine düşük oynaklıkların takip ettiği görülmektedir. Volatilite kümelenmesi (clustering) olarak bilinen bu durum finansal zaman serilerinin en önemli özelliklerinden birisidir. Bu özelliklerin en önemli sonucu ise varyansin zamana göre değişkenlik göstermesidir.

Finansal zaman serilerinin zayıf durağanlık özelliği taşımaları (Tablo 3) bu serilerin aynı zamanda güçlü durağan oldukları anlamına gelmemektedir. Güçlü durağanlık genellikle serilerin dağılım özelliklerine yönelik varsayımları gerektirmektedir. Söz konusu bu varsayımlar ise serinin üçüncü ve dördüncü momentine dayalı olarak belirlenen serinin dağılım özellikleridir. Bu varsayımın geçerliliği için kullanılan test ise Jarque-Bera normallik testidir (Tong:1990; Brockwell ve Davis:1987).

Tablo 2: Getiri Serilerine Ait Tanımlayıcı İstatistikler

\begin{tabular}{|c|c|c|}
\hline & LNDBIST100 & LNDAOFM \\
\hline Ortalama & 0.000173 & 0.000197 \\
\hline Medyan & 0.000837 & 0.000000 \\
\hline Maksimum & 0.062379 & 0.255442 \\
\hline Minimum & -0.110638 & -0.158860 \\
\hline Std Sapma & 0.015146 & 0.025592 \\
\hline Çarpıklık & -0.624403 & 1.688400 \\
\hline Basıklık & 7.276996 & 24.34538 \\
\hline Jarque Bera & $1034.797^{* * *}$ & $24343.83^{* * *}$ \\
\hline Gözlem & 1251 & 1251 \\
\hline
\end{tabular}

Tablo 2'de değişkenlere ait temel tanımlayıcı istatistikler yer almaktadır. Tabloda yer alan Jarque-Bera normal dağılım testine göre değişkenlerin normal dağıldıklarını ifade eden boş hipotez reddedilmektedir. Böylece her iki değişkenin de normal dağılmadığı görülmektedir. Bu sonuç serilerin güçlü durağan olmadıkları yönünde de bilgi sağlamaktadır. Ayrıca BİST100 serisi sola çarpık ve kalın kuyruk özelliği taşırken, ağırlıklı ortalama fonlama maliyetinin sağa çarpık ve leptokurtik (dik) bir yapı sergilediği görülmektedir. Dolayısıyla ele alınan değişkenler temel finansal zaman serisi özelliklerini taşımaktadır.

Tablo 3'te ele alınan değişkenlerin zayıf durağanlık özelliği taşıyıp taşımadıklarını test etmek amacıyla ADF ve KPSS birim kök testleri kullanılmıştır. 
Tablo 3: Birim Kök Test Sonuçları

\begin{tabular}{|c|c|c|c|c|}
\hline \multirow{2}{*}{ Değişkenler } & \multicolumn{2}{|c|}{ ADF Birim Kök Testi } & \multicolumn{2}{c|}{ KPSS Birim Kök Testi } \\
\cline { 2 - 5 } & Sabitli & $\begin{array}{c}\text { Sabitli ve } \\
\text { Trendli }\end{array}$ & Sabitli & $\begin{array}{c}\text { Sabitli ve } \\
\text { Trendli }\end{array}$ \\
\hline LNDBIST100 & $-36.506 * * *$ & $-36.508^{* * *}(0)$ & $0.075^{* * *}$ & $0.031^{* * *}$ \\
& $(0)$ & & $0.058^{* * *}$ & $0.055^{* * *}$ \\
\hline LNDAOFM & $-16.768^{* * *}$ & $-16.769^{* * *}(7)$ & $\% 1: 0.73$ & $\% 1: 0.21$ \\
& $(7)$ & $\% 1:-3.96$ & $\% 5: 0.46$ & $\% 5: 0.11$ \\
Kritik & $\% 1:-3.43$ & $\% 5:-3.41$ & $\% 10: 0.34$ & $\%: 0.11$ \\
\hline
\end{tabular}

Not:***,** ve $*$ sırasıyla \%1,\%5 ve \%10 önem düzeyindeki anlamlılıkları göstermektedir.

Elde edilen ADF birim kök testi sonuçlarına göre LNDBIST100 ve LNDAOFM değişkenlerinin hem sabitli hem de trendli modele ait test istatistikleri \%1 önem düzeyde kritik değerlerden küçük olduğu için söz konusu değişkenlerin zayıf durağan oldukları görülmüştür. KPSS birim kök testi ise değişkenlerin parçalı birim kök yapılarını dikkate alabilmektedir. Boş hipotezin durağanlığı ifade ettiği bu birim kök testinde ise değişkenlerin test istatistikleri kritik değerlerden küçük olduğundan dolayı boş hipotezler kabul edilmiş ve değişkenlerin zayıf durağan olduğu sonucuna varılmıştır. Böylece frekans düzeyinde zaman serilerinin ortalama durağanlıktan farklılık göstermediği görülmektedir (Brooks, 2014: 365).

Ele alınan serilerin oynaklık analizlerine geçmeden önce ilk olarak söz konusu serilerin zamana göre değişen varyans özelliği gösterip göstermedikleri ARCH-LM testiyle incelenmiştir. Bu amaçla öncelikle serilerin ARMA yapılarına ait gecikme uzunlukları belirlenmiştir. Gecikme uzunluklarının tespitinde AIC bilgi kriteri kullanılmıştır. Maksimum 12 olarak belirlenen gecikme uzunluğu E-views 9 paket programı Add-ins uzantısında yer alan "Automatic Arima Selection" algoritması kullanılarak LNDBİST100 için ARMA(7,10), LNDAOFM için $\operatorname{ARMA}(9,10)$ olarak tespit edilmiştir. Söz konusu bu gecikme uzunluklarının hata terimlerine uygulanan ARCHLM değişen varyans test sonuçları tablo 4 ve 5 'de yer almaktadır.

Tablo 4: LNDBİST100 ARCH-LM Değișen Varyans Test Sonuçları

\begin{tabular}{|l|c|c|c|}
\hline $\begin{array}{c}\text { F- } \\
\text { istatistiği }\end{array}$ & 5.617 & Olasılık & 0.000 \\
\hline Gözlem*R ${ }^{2}$ & 104.581 & $\chi^{2}$ (olasıllk) & 0.000 \\
\hline
\end{tabular}

Tablo 5: LNDAOFM ARCH-LM Değişen Varyans Test Sonuçları

\begin{tabular}{|l|l|l|c|}
\hline $\begin{array}{c}\text { F- } \\
\text { istatistiği }\end{array}$ & 5.617 & Olasılık & 0.000 \\
\hline Gözlem*R $^{2}$ & 104.581 & $\chi^{2}$ (olasılık) & 0.000 \\
\hline
\end{tabular}

Elde edilen değişen ARCH-LM değişen varyans test istatistiği sonuçlarına göre her iki getiri serisi için serilerin sabit varyanslı olduklarını ifade eden boş hipotezler reddedilmiş dolayısıyla serilerin zamana göre değişen varyans özelliğine sahip oldukları sonucuna varılmıştır.

Analitik bulguların elde edilmesinde Ox-Metrics 6 ve R yazılım programları kullanılmıştır.

Değişkenleri temsil eden serilerin değişen varyans özelliğine sahip olduğu sonuçlarına ulaşıldıktan sonra, oynaklığın yayıldığı piyasaya(LNDBİST100) ait oynaklık ve nedensellik analizi yapılmıştır. Söz konusu oynaklığın yayıldığı piyasanın analizinde simetrik AR(1)-GARCH(1,1)-M ve asimetrik AR(1)-GJR-GARCH(1,1)-M teknikleri kullanılarak parametre tahminleri yapılmıştır. Böylece bir yandan zaman serisinin varyans durağanlığı araştırılırken diğer taraftan şokun ortaya çıktığ 1 piyasadan diğer piyasaya doğru bir oynaklık yayılımının olup olmadı̆̆ varyans nedensellik testiyle incelenmiştir. 
Ekinci, R., Ceylan, F., Tuzun, O., Kahyaoglu, H. / Journal of Yasar University, 2016, 11/44, 263-277

Tablo 6: AR(1)-GARCH(1,1)-M Modeli: Ağırlıklı Ortalama Fonlama Maliyetinden BİST100'e Simetrik Yayılma Etkisi

\begin{tabular}{|c|c|c|c|c|c|}
\hline \multicolumn{2}{|c|}{ Katsayılar } & $\begin{array}{l}\text { Normal } \\
\text { Dağılım }\end{array}$ & GED Dağılımı & $\begin{array}{l}\text { Student-t } \\
\text { Dağılımı }\end{array}$ & $\begin{array}{c}\text { Skewed } \\
\text { Student-t Dağılımı }\end{array}$ \\
\hline \multicolumn{6}{|c|}{ Ortalama Eşitliği } \\
\hline \multicolumn{2}{|l|}{$c$} & $\begin{array}{l}0.001187 \\
(1.00)\end{array}$ & $\begin{array}{l}0.001710 \\
(4.477)^{* * *}\end{array}$ & $\begin{array}{l}0.001767 \\
(1.69)^{*}\end{array}$ & $\begin{array}{l}0.001546 \\
(1.437)\end{array}$ \\
\hline \multicolumn{2}{|l|}{$b$} & $\begin{array}{l}-2.857604 \\
(-0.511)\end{array}$ & $\begin{array}{l}-4.108675 \\
(-5.852) * * *\end{array}$ & $\begin{array}{l}-4.662681 \\
(-0.886)\end{array}$ & $\begin{array}{l}-4.955308 \\
(-0.917)\end{array}$ \\
\hline \multicolumn{2}{|l|}{$\delta$} & $\begin{array}{l}-0.014839 \\
(-0.481)\end{array}$ & $\begin{array}{l}-0.028213 \\
(-0.874)\end{array}$ & $\begin{array}{l}-0.027559 \\
(-0.983)\end{array}$ & $\begin{array}{l}-0.034445 \\
(-1.243)\end{array}$ \\
\hline \multicolumn{2}{|l|}{$\gamma$} & $\begin{array}{l}-0.010743 \\
(-0.062)\end{array}$ & $\begin{array}{l}-0.008536 \\
(-0.519)\end{array}$ & $\begin{array}{l}-0.007576 \\
(-0.438)\end{array}$ & $\begin{array}{l}-0.008818 \\
(-0.513)\end{array}$ \\
\hline \multicolumn{6}{|c|}{ Varyans Eşitliği } \\
\hline \multicolumn{2}{|l|}{$\omega$} & $\begin{array}{l}0.068955 \\
(0.852)\end{array}$ & $\begin{array}{l}0.033117 \\
(0.442)\end{array}$ & $\begin{array}{l}0.020109 \\
(0.737)\end{array}$ & $\begin{array}{l}0.020624 \\
(0.794)\end{array}$ \\
\hline \multicolumn{2}{|l|}{$\alpha$} & $\begin{array}{l}0.052819 \\
(1.483)\end{array}$ & $\begin{array}{l}0.037634 \\
(0.998)\end{array}$ & $\begin{array}{l}0.030790 \\
(1.775)^{*}\end{array}$ & $\begin{array}{l}0.031199 \\
(1.954)^{*}\end{array}$ \\
\hline \multicolumn{2}{|l|}{$\beta$} & $\begin{array}{l}0.916497 \\
(13.33) * * *\end{array}$ & $\begin{array}{l}0.947277 \\
(12.33) * * *\end{array}$ & $\begin{array}{l}0.960227 \\
(30.70) * * *\end{array}$ & $\begin{array}{l}0.959351 \\
(32.88) * * *\end{array}$ \\
\hline \multicolumn{2}{|l|}{$d$} & $\begin{array}{l}0.000108 \\
(0.097)\end{array}$ & $\begin{array}{l}0.000043 \\
(0.983)\end{array}$ & $\begin{array}{l}-0.000022 \\
(0.984)\end{array}$ & $\begin{array}{l}0.000012 \\
(0.911)\end{array}$ \\
\hline \multicolumn{2}{|c|}{ Student(DF) } & & & $\begin{array}{l}5.873384 \\
(5.901) * * *\end{array}$ & \\
\hline \multicolumn{2}{|c|}{ GED (DF) } & & $\begin{array}{c}1.284407 \\
(13.48) * * *\end{array}$ & & \\
\hline \multicolumn{2}{|c|}{$\kappa$ (asimetri) } & & & & $\begin{array}{l}-0.085356 \\
(-2.198) * *\end{array}$ \\
\hline \multicolumn{2}{|c|}{$v$ (kuyruk) } & & & & $\begin{array}{c}6.010140 \\
(5.896) * * *\end{array}$ \\
\hline \multicolumn{6}{|c|}{ Hipotez Testleri } \\
\hline \multicolumn{2}{|c|}{ AIC } & -5.631 & -5.698 & -5.711 & -5.713 \\
\hline \multicolumn{2}{|c|}{$\mathrm{BIC}$} & -5.598 & -5.661 & -5.674 & -5.672 \\
\hline \multirow{4}{*}{$\mathrm{LB}(\mathrm{Q})$} & $\mathrm{Q}(20)$ & $2.207(0.697)$ & $2.760(0.598)$ & $3.079(0.544)$ & $3.196(0.525)$ \\
\hline & $\mathrm{Q}(50)$ & $7.133(0.623)$ & $7.798(0.554)$ & $8.208(0.513)$ & $8.257(0.508)$ \\
\hline & $\mathrm{Q}(20)$ & $11.855(0.891)$ & $12.524(0.861)$ & $12.991(0.838)$ & $13.014(0.837)$ \\
\hline & $Q(50)$ & $39.232(0.839)$ & $40.171(0.811)$ & $40.722(0.793)$ & $40.850(0.789)$ \\
\hline \multirow{4}{*}{$\mathrm{LB}\left(\mathrm{Q}^{2}\right)$} & $Q^{2}(5)$ & $4.780(0.188)$ & $6.759(0.779)$ & $8.246(0.441)$ & $7.842(0.3493)$ \\
\hline & $Q^{2}(10)$ & $5.764(0.673)$ & $7.760(0.457)$ & $9.353(0.313)$ & $8.938(0.347)$ \\
\hline & $Q^{2}(20)$ & $13.455(0.763)$ & $15.025(0.660)$ & $16.681(0.545)$ & $16.171(0.580)$ \\
\hline & $Q^{2}(50)$ & $23.243(0.999)$ & $24.873(0.997)$ & $26.558(0.994)$ & $26.117(0.995)$ \\
\hline \multirow{3}{*}{$\mathrm{F}$} & $\mathrm{F}(2,1243)$ & $0.134(0.874)$ & $0.094(0.909)$ & $0.179(0.835)$ & $0.156(0.855)$ \\
\hline & $\mathrm{F}(5,1237)$ & $1.012(0.409)$ & $1.413(0.216)$ & $1.701(0.131)$ & $1.623(0.150)$ \\
\hline & $\mathrm{F}(10,1227)$ & $0.693(0.730)$ & $0.896(0.535)$ & $1051(0.397)$ & $1.008(0.443)$ \\
\hline
\end{tabular}

Not: Parantez içindeki değerler "t" istatistiki değerleridir. * \%1, ** \%5 anlamlılı̆̆ göstermektedir. Modele ait katsayıların anlamlılıklarını parantez içindeki t istatistikleri göstermektedir. Hipotez testlerine ait anlamlılıkları ise parantez içindeki olasılık değerleri göstermektedir. Bu değer 0.05 den küçük ise boş hipotez ret edilmektedir.

$* * *, * *$ ve $*$ sirasiyla $\% 1, \% 5$ ve $\% 10$ önem düzeyinde anlamlılıkları ifade etmektedir. 


$$
\begin{aligned}
& \text { LNDBIST } 100_{t}=c+b h_{t}+\delta L N D B \dot{I S T} 100_{t-1}+\gamma L N D A O F M_{t-1}+\varepsilon_{t} \\
& h_{t}=\omega+\alpha \varepsilon_{t-1}^{2}+\beta h_{t-1}+\lambda U_{t-1}^{2}
\end{aligned}
$$

Burada $L N D B \dot{I S T} 100_{t}$, $\mathrm{t}$ dönemi Borsa İstanbul 100 endeksi getirisini; $L N D A O F M_{t-1}, \mathrm{t}-1$ dönemine ait Merkez Bankası ağırlıklı ortalama fonlama maliyeti getirisini; $U_{t-1}^{2}$, ağırlıklı ortalama fonlama maliyetine (LNDAOFM) uygulanan $A R(1)-G A R C H(1,1)-\mathrm{M}$ modelinden elde edilen hata terimi karesini; $h_{t}$, Borsa İstanbul getiri serisinin $\left(L N D B \dot{I} S T 100_{t}\right)$ koşullu varyansını göstermektedir. $\mathrm{LB}(\mathrm{Q})$ ve $\mathrm{LB}\left(\mathrm{Q}^{2}\right)$ sırasıyla modelde otokorelasyonun olup olmadığını gösteren Ljung-Box $Q$ ve Ljung-Box $Q^{2}$ test istatistiklerini göstermektedir. F testi ise modelde değişen varyans olup olmadığını gösteren ARCH-LM test istatistiğidir. Her iki testin boş hipotezleri sırasıyla otokorelasyonun ve değişen varyansın olmadığını ifade etmektedir.

Tablo 6'da simetrik AR(1)-GARCH(1,1)-M modeline ait tahmin sonuçları yer almaktadır. Çalışmada oynaklığın koşullu ortalama üzerindeki etkisini de dikkate almak amacıyla, koşullu varyansın koşullu ortalamada açıklayıcı bir değişken olarak yer aldığı GARCH-M modeli tercih edilmiştir. Böylece merkez bankasının ağırlıklı ortalama fonlama maliyetinden kaynaklanan bir şoka bağlı olarak oluşan bir riskin BİST100 üzerindeki etkisi analiz edilebilmektedir. Ayrıca dağılım özelliğine bağlı olarak seriler üzerindeki asimetrik etkileri ortaya koymak amacıyla her bir oynaklık modeli GED ve Skewed Student $t$ dağılımına göre tahmin edilmiştir.

Tabloda yer alan AR(1)-GARCH(1,1)-M tahmin sonuçları incelendiğinde, varyans parametrelerinin pozitiflik koşulunu sağladığı ayrıca her bir dağılıma göre hesaplanan $(b+c<1)$ katsayıların varyans durağan oldukları görülmektedir. Bu sonuç şokların kalıcı olmadığı yönünde bilgi vermektedir. Diğer yandan GED dağılımına ait katsayının 2'den küçük olması serinin kalın kuyruk özelliğine sahip olduğu anlamına gelmektedir. Dolayısıyla bu durum kuyruk özelliğine bağlı olarak dağılımın asimetrik etkiler de gösterebileceği yönünde bir bilgidir. Elde edilen Skewed Student $t$ dağılımına ait $\kappa$ (asimetri) parametresinin anlamlı olması BİST100 endeksinin asimetrik bir dağılım özelliği gösterdiği anlamına gelmektedir. $v$ (kuyruk) parametresi ise dağılımın leptokurtik bir yap1 sergilediği yönünde bilgi vermektedir.

Hata terimimin karesine ait $\left(U_{t-1}^{2}\right)$ katsayılar tüm modeller için anlamsız bulunmuştur. Bu sonuç ağırlıklı ortalama fonlama maliyetinden (LNDAOFM), BİST100 endeksine doğru simetrik bir oynaklık yayılımının olmadığı yönünde bilgi sağlamaktadır.

Elde edilen tahmin sonuçlarının tutarlılığına yönelik tanı istatistikleri incelendiğinde otokorelasyonun olup olmadığını gösteren $Q$ ve $Q^{2}$ istatistikleri ile değişen varyansın olup olmadığını gösteren $F$ istatistiğine ait olasılık değerleri \%5 önem düzeyinde anlamsız bulunmuştur. Bu sonuç modellerin otokorelasyon ve değişen varyans taşıması dolayısıyla model sonuçlarının yorumlanabilmesi için gereklilik koşullarını yerine getirdikleri anlamına gelmektedir. 
Ekinci, R., Ceylan, F., Tuzun, O., Kahyaoglu, H. / Journal of Yasar University, 2016, 11/44, 263-277

Tablo 7:AR(1)-GJR-GARCH(1,1)-M Modeli: Yapısal Kırılmalar Altında Ağırlıklı Ortalama Fonlama Maliyetinden BİST100'e Asimetrik Yayılma Etkisi

\begin{tabular}{|c|c|c|c|c|c|}
\hline & Katsayılar & Normal Dağglım & GED Dağılımı & Student-t Dağılımı & $\begin{array}{c}\text { Skewed Student-t } \\
\text { Dağılımı }\end{array}$ \\
\hline \multicolumn{6}{|c|}{ Ortalama Eşitliği } \\
\hline \multicolumn{2}{|l|}{$c$} & $\begin{array}{l}0.008366 \\
(8.389) * * *\end{array}$ & $\begin{array}{l}0.005598 \\
(2.491)\end{array}$ & $\begin{array}{l}0.007844 \\
(2.338)^{* *}\end{array}$ & $\begin{array}{l}0.007595 \\
(0.226)\end{array}$ \\
\hline \multicolumn{2}{|l|}{$b$} & $\begin{array}{l}-0.0599 \\
(-0.088)\end{array}$ & $\begin{array}{l}-0.200603 \\
(-0.696)\end{array}$ & $\begin{array}{l}-0.188336 \\
(-0.012)\end{array}$ & $\begin{array}{l}-0.324407 \\
(-0.005)\end{array}$ \\
\hline \multicolumn{2}{|l|}{$\delta$} & $\begin{array}{l}0.032084 \\
(0.221)\end{array}$ & $\begin{array}{l}-0.009346 \\
(-0.091)\end{array}$ & $\begin{array}{l}0.006233 \\
(0.0151)\end{array}$ & $\begin{array}{l}0.014034 \\
(0.005)\end{array}$ \\
\hline \multicolumn{2}{|l|}{$\gamma$} & $\begin{array}{l}-0.001179 \\
(0.966)\end{array}$ & $\begin{array}{l}-0.004946 \\
(-0.210)\end{array}$ & $\begin{array}{l}-0.007336 \\
(-0.1996) \\
\end{array}$ & $\begin{array}{l}0.000166 \\
(0.089)\end{array}$ \\
\hline \multicolumn{6}{|c|}{ Varyans Eşitliği } \\
\hline \multicolumn{2}{|l|}{$\omega$} & $\begin{array}{l}0.049206 \\
(2.308)^{* *}\end{array}$ & $\begin{array}{l}0.064726 \\
(2.216)^{* *}\end{array}$ & $\begin{array}{l}0.0514 \\
(3.318) * * *\end{array}$ & $\begin{array}{l}0.0524 \\
(0.872)\end{array}$ \\
\hline \multicolumn{2}{|l|}{$\alpha$} & $\begin{array}{l}0.102423 \\
(1.461)\end{array}$ & $\begin{array}{l}0.095024 \\
(1.861)^{*}\end{array}$ & $\begin{array}{l}0.096331 \\
(1.703)^{*}\end{array}$ & $\begin{array}{l}0.106011 \\
(0.287)\end{array}$ \\
\hline \multicolumn{2}{|l|}{$\beta$} & $\begin{array}{l}0.0 .78576 \\
(16.25)^{* * *}\end{array}$ & $\begin{array}{l}0.795689 \\
(12.282) * * *\end{array}$ & $\begin{array}{l}0.790447 \\
(21.48) * * *\end{array}$ & $\begin{array}{l}0.0 .781003 \\
(1.199)\end{array}$ \\
\hline \multicolumn{2}{|l|}{$\lambda$} & $\begin{array}{l}0.000692 \\
(0.832)\end{array}$ & $\begin{array}{l}0.000575 \\
(0.715)\end{array}$ & $\begin{array}{l}0.000664 \\
(0.411)\end{array}$ & $\begin{array}{l}0.001077 \\
(0.125)\end{array}$ \\
\hline \multicolumn{2}{|l|}{$k$} & $\begin{array}{l}0.008049 \\
(0.080) \\
\end{array}$ & $\begin{array}{l}0.000901 \\
(0.990) \\
\end{array}$ & $\begin{array}{l}0.001930 \\
(0.026) \\
\end{array}$ & $\begin{array}{l}-0.008401 \\
(0.012) \\
\end{array}$ \\
\hline \multicolumn{2}{|l|}{$\theta$} & $\begin{array}{l}0.000662 \\
(18.29)^{* * *} \\
\end{array}$ & $\begin{array}{l}0.000675 \\
(15.36)^{* * *}\end{array}$ & $\begin{array}{l}0.000712 \\
(26.13) * * * \\
\end{array}$ & $\begin{array}{l}0.000762 \\
(2.710) * * *\end{array}$ \\
\hline \multicolumn{2}{|c|}{ Student (DF) } & & & $\begin{array}{l}6.018309 \\
(2.457)^{* *}\end{array}$ & \\
\hline \multicolumn{2}{|c|}{ GED (DF) } & & $\begin{array}{l}1.880909 \\
(18.72)^{* * * *}\end{array}$ & & \\
\hline \multicolumn{2}{|c|}{$\kappa$ (asimetri) } & & & & $\begin{array}{l}0.005701 \\
(0.989)\end{array}$ \\
\hline \multicolumn{2}{|c|}{$v$ (kuyruk) } & & & & $\begin{array}{l}6.023162 \\
(0.012) \\
\end{array}$ \\
\hline \multicolumn{6}{|c|}{ potez Testleri } \\
\hline \multicolumn{2}{|l|}{ AIC } & -5.108 & -5.351 & -5.258 & -5.265 \\
\hline \multicolumn{2}{|l|}{$\mathrm{BIC}$} & -5.067 & -5.306 & -5.213 & -5.216 \\
\hline \multirow{4}{*}{ LB } & $\mathrm{Q}(20)$ & $4.816(0.306)$ & $2.478(0.648)$ & $3.038(0.450)$ & $3.130(0.420)$ \\
\hline & $\mathrm{Q}(50)$ & $8.679(0.467)$ & $6.144(0.725)$ & $6.727(0.665)$ & $7.724(0.582)$ \\
\hline & $\mathrm{Q}(20)$ & $17.940(0.526)$ & $15.397(0.714)$ & $16.116(0.649)$ & $16.418(0.866)$ \\
\hline & $\mathrm{Q}(50)$ & $38.497(0.859)$ & $41.836(0.779)$ & $40.546(0.799)$ & $40.125(0.842)$ \\
\hline \multirow{4}{*}{$\mathrm{LB}\left(\mathrm{Q}^{2}\right)$} & $Q^{2}(5)$ & $3.232(0.299)$ & $2.477 .154(0.479$ & $2.623(0.453)$ & $2.609(0.455)$ \\
\hline & $Q^{2}(10)$ & $8.936(0.347)$ & $7.958(0.438)$ & $8.309(0.403)$ & $8.319(0.402)$ \\
\hline & $Q^{2}(20)$ & $22.623(0.203)$ & $18.879(0.399)$ & $21.936(0.234)$ & $22.426(0.213)$ \\
\hline & $Q^{2}(50)$ & $37.781(0.855)$ & $28.778(0.987)$ & $37.817(0.850)$ & $38.750(0.987)$ \\
\hline \multirow[t]{3}{*}{$\mathrm{F}$} & $\mathrm{F}(2,1243)$ & $0.825(0.438)$ & $0.420(0.657)$ & $0.590(0.586)$ & $0.648(0.584)$ \\
\hline & $\mathrm{F}(5,1237)$ & $0.609(0.693)$ & $0.467(0.800)$ & $0.486(0.786)$ & $0.485(0.787)$ \\
\hline & $\mathrm{F}(10,1227)$ & $1.158(0.314)$ & $1.227(0.268)$ & $1.081(0.373)$ & $1.267(0.381)$ \\
\hline
\end{tabular}

Not: Parantez içindeki değerler "t" istatistiki değerleridir. * \%1, ** \%5 anlamlılığ1 göstermektedir. Modele ait katsayıların anlamlılıklarını parantez içindeki t istatistikleri göstermektedir. Hipotez testlerine ait anlamlılıkları ise parantez içindeki olasılık değerleri göstermektedir. Bu değer 0.05 den küçük ise boş hipotez ret edilmektedir. ${ }^{* * *}$,** ve * sırasıyla $\% 1, \% 5$ ve $\% 10$ önem düzeyinde anlamlılıkları ifade etmektedir. 
LNDBİST $100_{\mathrm{t}}=\mathrm{c}+\mathrm{bh}_{\mathrm{t}}+\delta \mathrm{LNDBISST}_{100_{\mathrm{t}-1}}+\gamma$ LNDAOFM $_{\mathrm{t}-1}+\varepsilon_{\mathrm{t}}$ $\mathrm{h}_{\mathrm{t}}=\omega+\alpha \varepsilon_{\mathrm{t}-1}^{2}+\beta \mathrm{h}_{\mathrm{t}-1}+\lambda \mathrm{U}_{\mathrm{t}-1}^{2}+\mathrm{kS}_{\mathrm{t}-1} \mathrm{U}_{\mathrm{t}-1}^{2}+\theta \mathrm{DUM}$

Burada $L N D B \dot{I S T} 100_{t}$, $\mathrm{t}$ dönemi Borsa İstanbul 100 endeksi getirisini; $L N D A O F M_{t-1}, \mathrm{t}-1$ dönemine ait Merkez bankası ağırlıklı ortalama fonlama maliyeti getirisini; $U_{t-1}^{2}$, ağırlıklı ortalama fonlama maliyetine (LNDAOFM) uygulanan AR(1)-GARCH $(1,1)-\mathrm{M}$ modelinden elde edilen hata terimi karesini; $h_{t}$, Borsa İstanbul getiri serisinin $\left(L N D B I S T 100_{t}\right)$ koşullu varyansını; $S_{t}=1$, eğer $(L N D A O F M)$ den elde edilen $\varepsilon_{t}<0$ ise; diğer durumda ise $S_{t}=0$ göstermektedir. DUM, varyans kırılma testi sonucunda bulunan kırılma tarihini ifade etmektedir. LB $(\mathrm{Q})$ ve $\mathrm{LB}\left(\mathrm{Q}^{2}\right)$ sırasıyla modelde otokorelasyonun olup olmadığını gösteren Ljung-Box $Q$ ve Ljung-Box $Q^{2}$ test istatistiklerini göstermektedir. $F$ testi ise modelde değişen varyans olup olmadığını gösteren ARCH-LM test istatistiğidir. Her iki testin boş hipotezleri sırasıyla otokorelasyonun ve değişen varyansın olmadığını ifade etmektedir.

Tablo 7'de asimetrik AR(1)-GJR-GARCH(1,1)-M modeline ait tahmin sonuçları yer almaktadır. Çalışmada öncelikle kırılma yılları dikkate alınmaksızın katsayı tahminleri yapılmıştır. Elde edilen sonuçlar incelendiğinde normal dağılım dışındaki dağılımlara göre hesaplanan ARCH parametresinin negatif olduğu görülmektedir. Buna göre söz konusu dağılımlara göre hesaplanan ARCH katsayıları varyansın pozitifliği koşulunu sağlamamaktadır (bakınız ek1). Bu nedenle Hsu (1979)'nun 'Detecting Shifts of Parameter in Gamma Sequences with Applications to Stock Price and Air Traffic Flow Analysis" adlı çalışmasına dayanarak varyanstaki kırılmalar tespit edilmiş ve modele dâhil edilmiştir ${ }^{1}$. Buna göre 25/5/2014 ve 1/12/2014 dönemlerinde varyansta 2 kırılma tespit edilmiştir. Dolayısıyla bu sonuç 2 kırılmaya bağlı olarak sistemde 3 rejimin olduğunu göstermektedir.

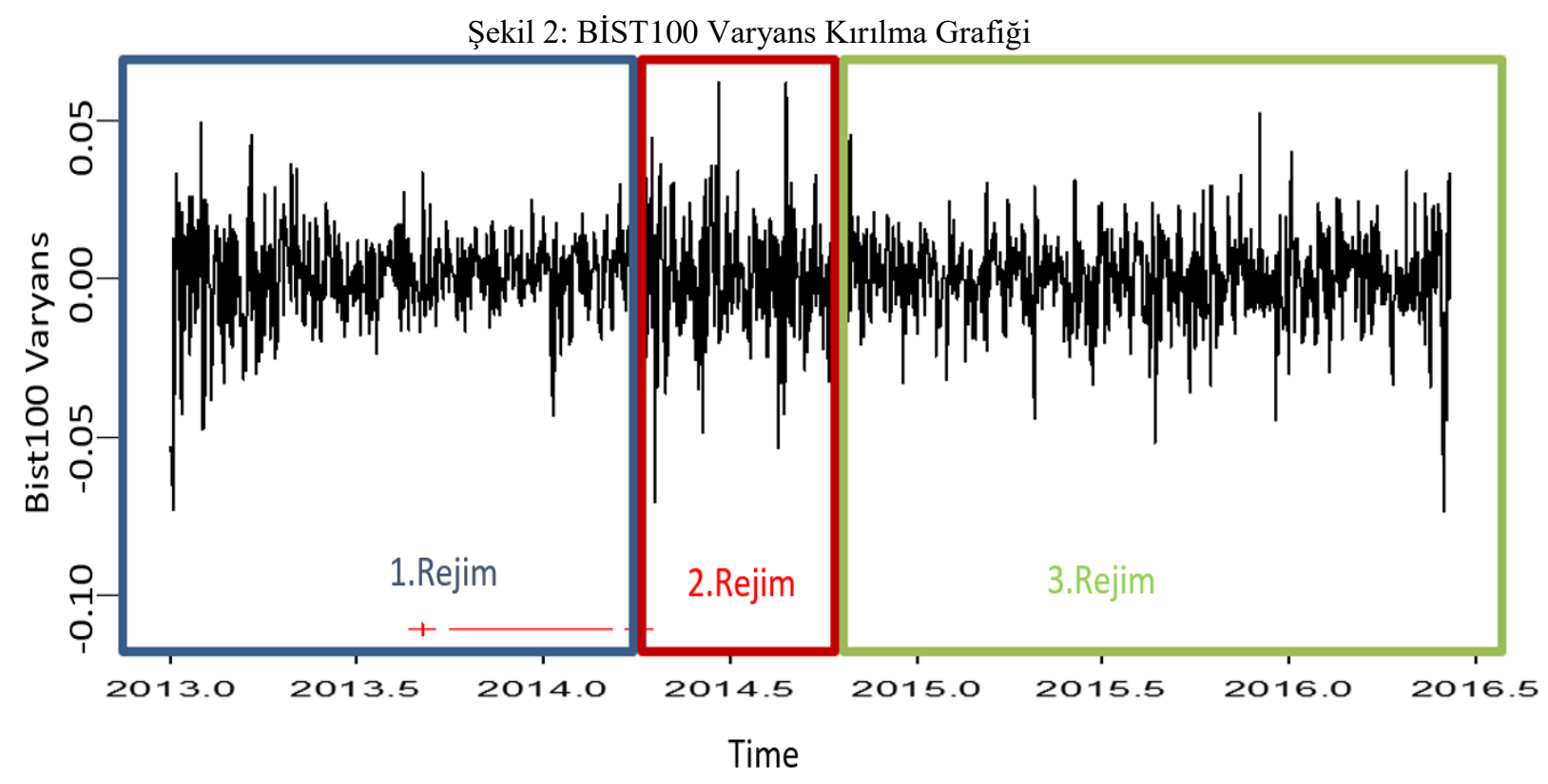

Bu çalışmada tespit edilen kırılma tarihleri arasındaki dönemler içinde varyansı en büyük olan ikinci rejimdir. Bu rejim şekilde kırmızı kutucuk içinde gösterilen alan arasındaki döneme denk gelmektedir. Böylece bu dönemlere 1, diğer dönemlere 0 verilerek oluşturulan kukla değişkenler modele dâhil edilerek katsayı tahminleri yapılmıştır.

Tablo 7'de elde edilen sonuçlara göre ARCH $(\alpha)$ ve GARCH $(\beta)$ parametreleri pozitiflik $(\alpha+\beta>0)$ ve durağanlık $(\alpha+\beta<1)$ koşullarını sağlamaktadır. Ayrıca kırılma dönemlerini temsil eden kukla değişkenin $(\theta)$ de bütün modellerde pozitif ve anlamlı olduğu görülmektedir. Katsayının pozitif olması söz konusu dönemde serinin varyansında bir artışın olduğunu göstermektedir. Ekte yer alan kırılmasız modelin aksine, ağıllıklı ortalama fonlama maliyetinin $(L N D A O F M)$ varyansına $\left(U_{t-1}^{2}\right)$ bağlı olarak oluşturulan ve varyanstaki asimetrik yayılımı ifade eden $\operatorname{GJR}(k)$ parametresi incelendiğinde katsayının bütün modeller için anlamsız olduğu görülmektedir. Bu sonuç

1 Varyans kırılmaların tespitinde açık yazılım programı R-project'e ait "strucchange" paketinden yararlanılmıştır. 
LNDAOFM'nin varyansındaki yayılımın simetrik olduğunu göstermektedir. Hata terimlerinin karesine $\left(U_{t-1}^{2}\right)$ ait katsayılar $(\lambda)$ ise bütün modeller için anlamsız bulunmuştur. Buna göre ağırlıklı ortalama fonlama maliyetinden (LNDAOFM) BİST100 endeksine (LNDAOFM) doğru simetrik bir oynaklık yayılımı söz konusu değildir. Buna karşın BİST100 endeksi için Skewed Student-t dağılımı dişında diğer dağılımlara göre elde edilen ARCH ve GARCH parametreleri anlamlıdır. Bu durum BİST100'de şokların etkili ve sürekli olduğu yönünde bir bilgi sağlamaktadır.

Elde edilen tahmin sonuçlarının tutarlılığına yönelik tanı istatistiklerine göre otokorelasyonun olup olmadığını gösteren $Q$ ve $Q^{2}$ istatistikleri ile değişen varyansın olup olmadığını gösteren $F$ istatistiğine ait olasılık değerleri incelendiğinde modellerde otokorelasyon ve değişen varyans probleminin olmadığı anlaşılmaktadır.

\section{Sonuç}

Merkez bankalarının finansal piyasalarda likidite düzeyini ayarlarken kullandığı araçlara göre gerçekleşen faiz oranlarının hisse senetleri piyasası üzerindeki olası etkileri parasal aktarım mekanizması çerçevesinde ele alınmaktadır. Ancak finansal piyasalarda ortaya çıkan finansal yenilikler ile teknolojik gelişmeler söz konusu değişkenlerin arasındaki oynaklıklar analizi önem kazanmıştır. Bu çerçevede likidite şoklarının finansal piyasalar üzerindeki etkisi de analiz edilmeye başlanmıştır. Likidite göstergelerinin hisse senetleri piyasasının oynaklığ üzerindeki etkisi, söz konusu likiditede ortaya çıkan değişimlerin, hisse senetleri piyasasında ortaya çıkan risk düzeyi üzerindeki etkiyi de göstermektedir.

Bu çalışmada simetrik ve asimetrik GARCH modelleri ile birlikte Moon ve Yu (2010)'un yaklaşımına dayalı olarak geliştirilen varyans nedensellik testi kullanılarak yukarıda belirtilen ilişkilerle ilgili sonuçlar ortaya konmuştur. Bu amaçla Merkez Bankası'nın ağırlıklı ortalama fonlama maliyetlerinden BİST100 endeksine doğru simetrik ve asimetrik bir oynaklık yayılımının olup olmadığı test edilmiştir. Elde edilen bulgulara göre TCMB'nin ortalama fonlama maliyetinin değişkenliğinden Borsa İstanbul oynaklığına bu çalışmada kullanılan yaklaşıma göre bir nedensellik bulunmamıştır. Buna göre negatif ve pozitif likidite şoklarından hisse senetleri piyasasına bir oynaklık yayılımının olmadığı ifade edilebilir. Bununla birlikte bu sonuç TCMB'nin piyasayı fonlaması sonucunda oluşan faiz oranlarındaki değişikliklerin hisse senetleri piyasasında oynaklı̆̆ı azaltıcı etkisinin olmadığını göstermektedir. Bu sonuç para piyasası ile kredi piyasası arasında bir ayrışmanın olduğu yönünde bir bilgi olarak değerlendirilmektedir. Türkiye ekonomisinde şirketlerin işletme sermayesini bile kredi piyasasından karşıladığı dikkate alınırsa, para ve sermaye piyasaları arasında bir bölünmenin olduğu söylenebilir. Ayrıca TCMB'nin bankalar açısından son kredi mercii olma özelliği söz konusu iken, hisse senedi piyasası üzerinde bu mekanizma vasıtası ile bir etki meydana getiremediği söylenebilir. Başka bir deyişle hisse senedi piyasasındaki yatırımcıların TCMB'nin AOFM göstergesine dayalı yatırım kararları üzerinde etkisinin olmadığı ifade edilebilir.

Buna göre ortalama fonlama maliyeti üzerinde etkili olan bir şokun hisse senetleri piyasası üzerinde etkisinin olmadığ $\breve{1}_{1}$ fade edilebilir. Burada ortalama fonlama maliyetini etkileyen para politikası kararları da birer şok olarak düşünülebilir. Bu açıdan değerlendirildiğinde faiz oranları ile hisse senedi piyasası arasında var olduğu kabul edilen ilişkiye, kullanılan yüksek frekanslı zaman serisi analizi sonuçlarına göre ulaşılmamıştır. Bu durum düşük frekanslı zaman serileri ile yapılan analiz sonuçları literatürde bir bulmaca (puzzle) oluşturmuştur.

Elde edilen bulgulara göre Merkez Bankası'nın likidite yönetiminden kaynaklı bir şokun hisse senetleri piyasasının oynaklığı üzerinde etkisinin olmamasının nedeni olarak iki piyasanın ayrışmış olması ifade edilebilir. $\mathrm{Bu}$ açıdan; hisse senedi piyasasının dış piyasalarla ilişkili olduğu ve bu çerçevede yatırımcılarının davranış oluşturduğu söylenebilir. Ayrıca Türkiye'de hisse senedi piyasası ve Tobin Q parasal aktarım mekanizmasının işlemediği görülmüştür. Bu kapsamda Türkiye'de genel olarak banka ağırlıklı bir finansal yapının ve buna bağlı olarak kredi aktarım mekanizmalarının daha etkili olduğu düşüncesinden hareketle bu konuda araştırmaların yapılması önerilmektedir. Merkez bankasının ekonominin likiditesine göre yapmış olduğu ayarlamalar ile politika faiz oranı arasında doğrudan bir ilişkinin araştırılması gerektiği ve bunun sonucu olarak da faiz koridoru politikasının yeniden ele alınması gerektiği sonucuna ulaşılmıştır. 


\section{KAYNAKÇA}

Alaganar, V., \& Bhar, R. 2003. "An international study of causality-in-variance: Interest rate and financial sector returns." Journal of Economics and Finance, 27, 39-55.

Ballester, L., Ferrer, R., \& González, C. 2011. "Linear and nonlinear interest rate sensitivity of Spanish banks." Spanish Review of Financial Economics, 9, 35-48.

Bartram, S. M. 2002. "The interest rate exposure of nonfinancial corporations." Review of Finance, 6, 101-125.

Bjørnland, H. C., \& Leitemo, K. 2009. "Identifying the interdependence between US monetary policy and the stock market." Journal of Monetary Economics, 56, 275-282

Bohl, M.T., P.L. Siklos ve D. Sondermann. 2007. "European stock markets and the ECB's monetary policy surprises." International Finance 11 (2), 117-130.

Bollerslev, T. 1986. "Generalized autoregressive conditional heteroscedasticity". Journal of Econometrics, 3,pp. 233-253.

Bollerslev, T. 1987. “A conditionally heteroskedastic time series model for speculative prices and rates of returns". Review of Economics and Statistics, 69, pp. 542-547.

Brockwell, P. J. \& Davis, R. A. 1987. Time Series: Theory and Methods. Springer Series in Statistics. New York, USA: Springer Verlag.

C. M. Hafner ve H. Herwartz. 2006. “A Lagrange multiplier test for causality in variance.” Economics Letters, Vol. 93, No. 1, 137-141.

Campbell, J. Y., \& Ammer, J. 1993. "What moves the stock and bond markets? A variance decomposition for longterm asset returns." The Journal of Finance, 48, 3-37.

Chan, K. C., Norrbin, S. C., \& Lai, P. 1997. “Are stock and bond prices collinear in the long run?" International Review of Economics and Finance, 6, 193-201.

Chris, Brooks. 2014. Introduction to Econometrics for Finance, Cambridge University Press.

Czaja, M., Scholz, H., \& Wilkens, M. 2009. "Interest rate risk of German financial institutions: The impact of level, slope, and curvature of the term structure." Review of Quantitative Finance and Accounting, 33, 1-26.

Czaja, M., Scholz, H., Wilkens, M., 2010. "Interestrate risk rewards in stock returns of financial corporations: evidence from Germany." Eur. Financ. Manage. 16, 124-154.

Das, A. 2005. "Do stock prices and interest rates possess a common trend?" Louvain Economic Review, 71, 383390.

Dinenis, E., \& Staikouras, S. K. 1998. "Interest rate changes and common stock returns of financial institutions: Evidence from the UK." European Journal of Finance, 4, 113-127.

Discussion Paper No. 463.https://www.fernuni hagen.de/wirtschaftswissenschaft/download/beitraege/db4 63.pdf

Duran, M., P. Özlü ve D. Ünalmış. 2010. “TCMB faiz kararlarının ve hisse senedi piyasaları üzerine etkisi.” Central Bank Review, Vol. 10 (July 2010), pp.23-32

Ehrmann, M., M. Fratzscher ve R. Rigobon. 2005. "Stocks, bonds, money markets and exchange rates: Measuring international financial transmission." NBER working paper no.11166.

Elyasiani, E., \& Mansur, I. 1998. "Sensitivity of the bank stock returns distribution to changes in the level and volatility of interest rate: A GARCH-M model." Journal of Banking \& Finance, 22, 535-563.

Engle, R. 1982. "Autoregressive conditional heteroscedasticity with estimates of the variance of U.K. inflation". Econometrica, 50, pp. 987-1008.

Engle, R. ve Ng, V. 1993. "Measuring and testing the impact of news on volatility." Journal of Finance, 48(5), pp. 1749-1778.

Engle, R., Lilien, D. ve Robins, R. .1987. "Estimating time varying risk premia in the term structure: the ARCH-M model." Econometrica, 55, pp. 391-407.

Faff, R. W., Hodgson, A., \& Kremmer, M. L. 2005. "An investigation of the impact of interest rates and interest rate volatility on Australian financial sector stock return distributions." Journal of Business, Finance \& Accounting, 32, 1001-1032.

Ferrer, R., Bolos, V. J., \& Benitez, R. 2016. "Interest rate changes and stock returns: A European multi-country study with wavelets." International Review of Economics and Finance, 44, 1-12.

Flannery, M. J., \& James, C. 1984. "The effect of interest rate changes on the common stock returns of financial institutions." The Journal of Finance, 39, 1141-1153.

Glosten, L., Jagannathan, R. ve Runkle, D. 1993. "On the relation between the expected value and the volatility of the nominal excess return on stocks". Journal of Finance, 48(5), pp. 1779-1801.

González M. 2016. "Asymmetric causality in-mean and in-variance among equity markets indexes". North American Journal of Economics and Finance, Volume 36, 49-68 http://dx.doi.org/10.1016/j.najef.2015.11.004

Gyu-Hyun Moon ve Wei-Choun Yu. 2010. "Volatility Spillovers between the US and China Stock Markets: Structural Break Test with Symmetric and Asymmetric GARCH Approaches”. Global Economic Review, Cilt: 39, Sayı:2, June. 
Hatemi-J, A., \& Roca, E. D. 2008. "Estimating banks' equity duration: A panel cointegration approach.” Applied Financial Economics, 18, 1173-1180.

Hsu D. A. 1979. "Detecting Shifts of Parameter in Gamma Sequences with Applications to Stock Price and Air Traffic Flow Analysis." Journal of the American Statistical Association, 74, 31-40.

Kanas.A ve Kouretas.G.P. 2002. "Mean and Variance Causality between Official and Parallel Currency Markets: Evidence from Four Latin American Countries". The Financial Review 37, 137-164.

Kasman, S., Vardar, G., \& Tunç, G. 2011. "The impact of interest rate and exchange rate volatility on banks' stock returns and volatility: Evidence from Turkey." Economic Modelling, 28, 1328-1334.

Kholodilin, K., A. Montagnoli, O. Napolitano ve B. Siliverstovs. 2009. "Assessing the impact of the ECB's monetary policy on the stock markets: A sectoral view." Economics Letters 105, 211-213.

Knütter, R. Mohr, B. ve Wagner H., 2011. "The Effects of Central Bank Communication on Financial Stability: A Systematization of the Empirical Evidence." Fernuniversität Hagen

Korkeamäki, T. 2011. "Interest rate sensitivity of the European stock markets before and after the euro introduction." Journal of International Financial Markets Institutions and Money, 21, 811-831.

Laopodis, N. T. 2010. "Dynamic linkages between monetary policy and the stock market." Review of Quantitative Finance and Accounting, 35, 271-293.

Martínez,M.P., Lapena,F.R., ve Sotos, E.F. 2015. "Interest rate changes and stock returns in Spain: A wavelet analysis.” BRQ Business Research Quarterly (2015) 18, 95-110

Mishkin F. S., 2001. "The Transmission Mechanism and the Role of Asset Prices in Monetary Policy," NBER Working Papers 8617, National Bureau of Economic Research, Inc.

Okur. M ve Cevik. E. 2013. “Testing Intraday Volatility Spillovers In Turkish Capital Markets: Evidence From ISE.” Economic Research-Ekonomska Istraživanja, Vol. 26, No. 3 (2013): pp. 99-116.

Panda, C. 2008. "Do interest rates matter for stock markets?" Economic and Political Weekly, 43, $107-115$.

Prasad, A. M., \& Rajan, M. 1995. "The role of exchange and interest risk in equity valuation: a comparative study of international stock markets." Journal of Economics and Business, 47, 457-472.

Reilly, F. K., Wright, D. J., \& Johnson, R. R. 2007. "Analysis of the interest rate sensitivity of common stocks." Journal of Portfolio Management, 33, 85-107.

Rigobon, R. ve B. Sack. 2004. "The impact of monetary policy on asset prices.” Journal of Monetary Economics $51,1553-1575$

Sensoy, A., \& Sobac1, C. 2014. "Effects of volatility shocks on the dynamic linkages between Exchange rate, interest rate and stock market: The case of Turkey." Economic Modelling, 43, 448-457.

Shah, A., Rehman, J. U., Kamal, Y., \& Abbas, Z. 2012. "The interest rates-stock prices nexus in highly volatile markets: Evidence from Pakistan.” Journal of Basic and Applied Scientific Research, 2, 2589-2598.

Sweeney, R. J., \& Warga, A. D. 1986. "The pricing of interest rate risk: evidence from the stock market." The Journal of Finance, 41, 393-410.

Tong, H. 1990. Non-linear Time Series: A Dynamical System Approach, Oxford University Press, New York.

Y. Hong. 2001. "A test for volatility spillover with application to exchange rates." Journal of Econometrics, Vol. 103, No. 1-2, 183-224.

Y. W. Cheung ve L. K. Ng. 1996. “A causality in variance test and its application to financial market prices.” Journal of Econometrics, Vol. 72, No. 33-48. 
Ekinci, R., Ceylan, F., Tuzun, O., Kahyaoglu, H. / Journal of Yasar University, 2016, 11/44, 263-277

EK.1:Varyans Kırılma Testleri
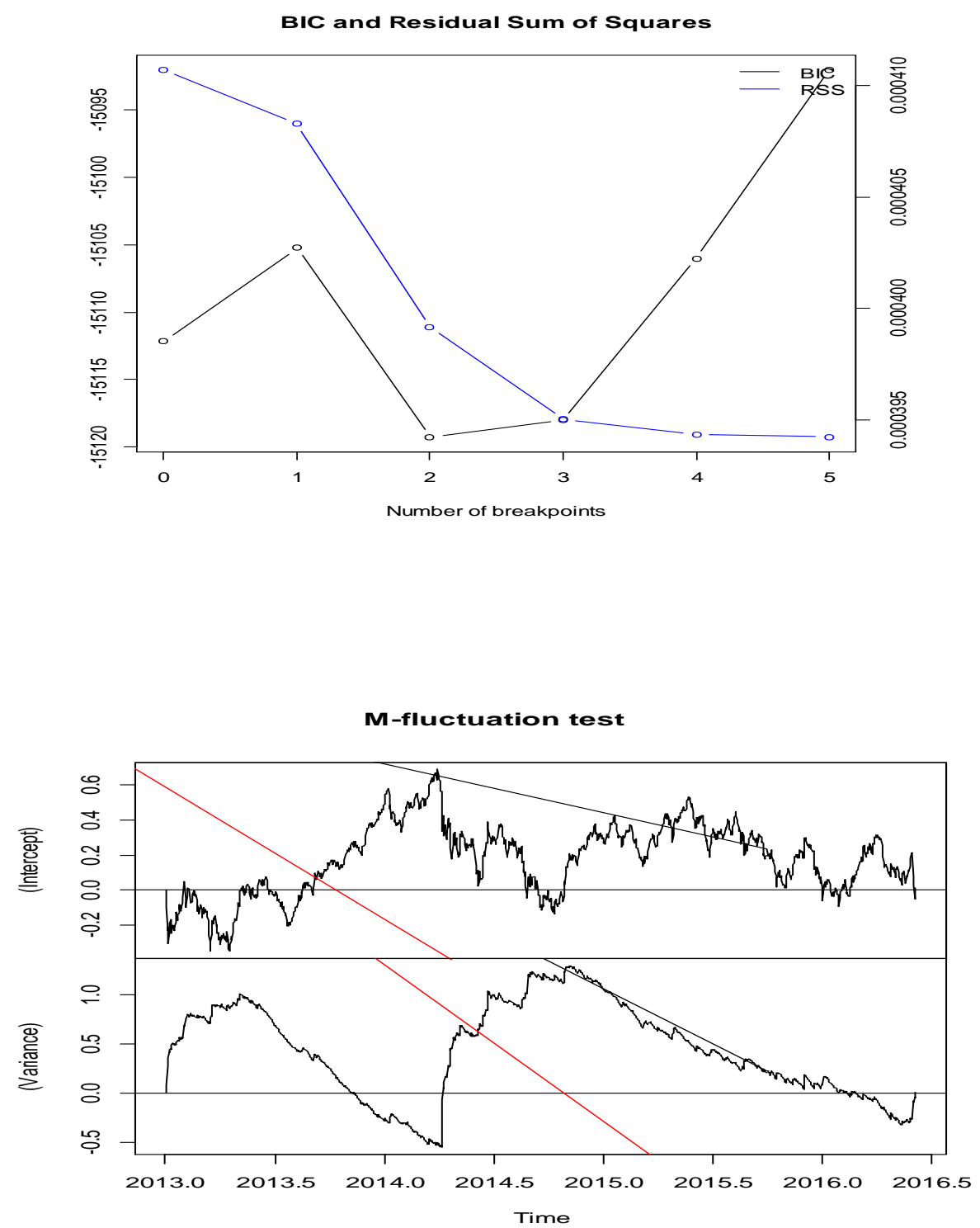

EK 2:

AR(1)-GJR-GARCH(1,1)-M Modeli: Yapısal Kırılmaları Dikkate Almaksızın Ağırlıklı Ortalama Fonlama Maliyetinden BİST100'e Asimetrik Yayılma Etkisi

\begin{tabular}{|c|c|c|c|c|}
\hline Katsayılar & $\begin{array}{l}\text { Normal } \\
\text { Dağılım }\end{array}$ & GED Dağılımı & $\begin{array}{l}\text { Student-t } \\
\text { Dağılımı }\end{array}$ & $\begin{array}{c}\text { Skewed } \\
\text { Student-t Dağılımı }\end{array}$ \\
\hline \multicolumn{5}{|c|}{ Ortalama Eşitliği } \\
\hline$\alpha$ & $\begin{array}{l}0.001 \\
(1.060)\end{array}$ & $\begin{array}{l}0.001 \\
(1.534)\end{array}$ & $\begin{array}{l}0.001 \\
(1.387)\end{array}$ & $\begin{array}{l}0.001 \\
(1.096)\end{array}$ \\
\hline$\beta$ & $\begin{array}{l}-3.786 \\
(-0.762)\end{array}$ & \begin{tabular}{|l|}
-3.799 \\
$(-0.696)$
\end{tabular} & $\begin{array}{l}-3.534 \\
(-0.697)\end{array}$ & $\begin{array}{l}-3.496 \\
(-0.696)\end{array}$ \\
\hline$\delta$ & $\begin{array}{l}-0.012 \\
(-0.446)\end{array}$ & $\begin{array}{l}-0.033 \\
(-1.177)\end{array}$ & $\begin{array}{l}-0.032 \\
(-1.207)\end{array}$ & $\begin{array}{l}-0.038 \\
(-1.461)\end{array}$ \\
\hline$\gamma$ & $\begin{array}{l}-0.011 \\
(-0.649)\end{array}$ & $\begin{array}{l}-0.008 \\
(-0.351)\end{array}$ & $\begin{array}{l}-0.006 \\
(-0.340)\end{array}$ & $\begin{array}{l}-0.007 \\
(-0.449)\end{array}$ \\
\hline \multicolumn{5}{|c|}{ Varyans Eşitliği } \\
\hline
\end{tabular}


Ekinci, R., Ceylan, F., Tuzun, O., Kahyaoglu, H. / Journal of Yasar University, 2016, 11/44, 263-277

\begin{tabular}{|c|c|c|c|c|c|}
\hline \multicolumn{2}{|l|}{$a$} & $\begin{array}{l}0.076 \\
(0.895)\end{array}$ & $\begin{array}{l}0.014 \\
(1.215)\end{array}$ & $\begin{array}{l}0.013 \\
(1.333)\end{array}$ & $\begin{array}{l}0.014 \\
(1.481)\end{array}$ \\
\hline \multicolumn{2}{|l|}{$b$} & $\begin{array}{l}0.003 \\
(0.202)\end{array}$ & $\begin{array}{l}-0.017 \\
(-1.425)\end{array}$ & $\begin{array}{l}-0.020 \\
(-2.018) * *\end{array}$ & $\begin{array}{l}-0.022 \\
(-2.301) * *\end{array}$ \\
\hline \multicolumn{2}{|l|}{$c$} & $\begin{array}{l}0.918 \\
(12.46)^{* * *}\end{array}$ & \begin{tabular}{|l|}
0.982 \\
$(64.87) * * *$ \\
\end{tabular} & $\begin{array}{l}0.983 \\
(91.65)^{* * *}\end{array}$ & $\begin{array}{l}0.984 \\
(100.9) * * *\end{array}$ \\
\hline \multicolumn{2}{|l|}{$d$} & $\begin{array}{l}-0.000 \\
(-0.100)\end{array}$ & $\begin{array}{l}-0.000 \\
(-1.535)\end{array}$ & $\begin{array}{l}-0.000 \\
(-0.847)\end{array}$ & $\begin{array}{l}-0.000 \\
(-0.686)\end{array}$ \\
\hline \multicolumn{2}{|l|}{$k$} & $\begin{array}{l}0.084 \\
(1.379)\end{array}$ & $\begin{array}{l}0.053 \\
(3.778) * * *\end{array}$ & $\begin{array}{l}0.056 \\
(4.595) * * *\end{array}$ & $\begin{array}{l}0.058 \\
(4.974) * * *\end{array}$ \\
\hline \multicolumn{2}{|c|}{ Student(DF) } & & & $\begin{array}{l}6.314 \\
(5.506)^{* *}\end{array}$ & \\
\hline \multicolumn{2}{|c|}{ GED (DF) } & & $\begin{array}{l}1.309 \\
(12.72) * * *\end{array}$ & & \\
\hline \multicolumn{2}{|c|}{$\kappa$ (asimetri) } & & & & $\begin{array}{l}-0.101 \\
(-2.624) * *\end{array}$ \\
\hline \multicolumn{2}{|c|}{$v$ (kuyruk) } & & & & $\begin{array}{l}6.521 \\
(5.485) * * *\end{array}$ \\
\hline \multicolumn{6}{|c|}{ Hipotez Testleri } \\
\hline \multicolumn{2}{|c|}{ AIC } & -5.645 & -5.707 & -5.724 & -5.727 \\
\hline \multicolumn{2}{|c|}{$\mathrm{BIC}$} & -5.608 & -5.666 & -5.683 & -5.682 \\
\hline LB & $\begin{array}{l}Q(20) \\
Q(50 \\
Q(20) \\
Q(50\end{array}$ & \begin{tabular}{|l}
2.307 \\
$(0.679)$ \\
6.539 \\
$(0.684)$ \\
11.503 \\
$(0.905)$ \\
38.497 \\
$(0.859)$ \\
\end{tabular} & \begin{tabular}{|l}
3.492 \\
$(0.478)$ \\
7.418 \\
$(0.593)$ \\
12.397 \\
$(0.867)$ \\
38.836 \\
$(0.850)$ \\
\end{tabular} & \begin{tabular}{|l}
3.686 \\
$(0.450)$ \\
7.478 \\
$(0.587)$ \\
12.376 \\
$(0.868)$ \\
39.098 \\
$(0.843)$ \\
\end{tabular} & $\begin{array}{l}3.894 \\
(0.420) \\
7.526 \\
(0.582) \\
12.418 \\
(0.866) \\
39.125 \\
(0.842)\end{array}$ \\
\hline $\mathrm{LB}\left(\mathrm{Q}^{2}\right)$ & $\begin{array}{l}Q^{2}(5) \\
Q^{2}(10) \\
Q^{2}(20) \\
Q^{2}(50)\end{array}$ & \begin{tabular}{|l|}
3.672 \\
$(0.299)$ \\
5.378 \\
$(0.716)$ \\
13.493 \\
$(0.761)$ \\
23.080 \\
$(0.999)$ \\
\end{tabular} & $\begin{array}{l}9.154 \\
(0.027 * *) \\
10.760 \\
(0.215) \\
18.879 \\
(0.399) \\
28.778 \\
(0.987) \\
\end{array}$ & $\begin{array}{l}9.505 \\
(0.023 * *) \\
11.352 \\
(0.182) \\
19.271 \\
(0.375) \\
29.138 \\
(0.985) \\
\end{array}$ & $\begin{array}{l}9.255 \\
(0.026 * *) \\
11.165 \\
(0.192) \\
18.934 \\
(0.395) \\
28.750 \\
(0.987)\end{array}$ \\
\hline $\mathrm{F}$ & $\begin{array}{l}F(2,1243) \\
F(5,1237) \\
F(10,1227)\end{array}$ & $\begin{array}{l}0.418 \\
(0.658) \\
0.799 \\
(0.549) \\
0.678 \\
(0.745) \\
\end{array}$ & $\begin{array}{l}0.420 \\
(0.657) \\
1.913 \\
(0.089) \\
1.227 \\
(0.268) \\
\end{array}$ & $\begin{array}{l}0.533 \\
(0.586) \\
1.972 \\
(0.080) \\
1.284 \\
(0.233) \\
\end{array}$ & $\begin{array}{l}0.537 \\
(0.584) \\
1.925 \\
(0.087) \\
1.267 \\
(0.243) \\
\end{array}$ \\
\hline
\end{tabular}

